\title{
Seasonal incidence of maize stem borer-record of new stage and site of oviposition of Sesamia inferens
}

\author{
M. ANURADHA*, M. LAVKUMAR REDDY AND D. SREELATHA
}

Maize Research Centre, Agricultural Research Institute, Rajendranagar, HYDERABAD (TELANGANA) INDIA

\section{ARITCLE INFO}

Received : 26.05 .2017

Revised : 13.09 .2017

Accepted : 24.09 .2017

\section{KEY WORDS :}

Maize stem, Borer-record, New stage, Site, Oviposition, Sesamia inferens

*Corresponding author:

\begin{abstract}
:
A field experiment on seasonal incidence of stem borers in corn was conducted at Maize Research Centre, Rajendranagar, Hyderabad. Undertaking sowings at monthly intervals from Jan 2013 to Dec 2013 in an area of $150 \mathrm{~m}^{2}$ as a replicated trial. DHM 117 hybrid was sown in ridge and furrow method at $75 \times 20 \mathrm{~cm}$ spacing. Random destructive sampling was done twice at 30 and 60 DAG @ 4 plants per replication to quantify the genera wise stem borer larval population and also stem tunneling. Observations on stem borer incidence and yield were recorded. Data was subjected to arcsine and square root transformation and two way analysis was conducted. It is evident from the results that among the monthly sowings, September and February are subjected to severe stem borer attack, however, low yields are observed in summer. Hence, it is advisable to take up sowings in July during Kharif and in November during Rabi to obtain maximum yields with low stem borer incidence.
\end{abstract}

How to view point the article : Anuradha, M., Reddy, M. Lavkumar and Sreelatha, D. (2017). Seasonal incidence of maize stem borer-record of new stage and site of oviposition of Sesamia inferens. Internat. J. Plant Protec., 10(2) : 438-441, DOI : 10.15740/HAS/IJPP/10.2/438-441. 